\title{
The Effect of Board Characteristics on Financial Performance: Case of Erbil
}

\section{Hawkar Anwer Hamad}

Department of Business Administration, College of Administration and Economics, Lebanese French University, Erbil, Kurdistan Region, Iraq

Hawker.anwar@lfu.edu.krd

\section{Akar Omar Mhammad}

Department of Accounting, College of Administration and Economics, Lebanese French University, Erbil, Kurdistan Region, Iraq

akaromar@lfu.edu.krd

\section{Wafa Rashid Mahmood}

Department of Accounting, College of Administration and Economics, Lebanese French University, Erbil, Kurdistan Region, Iraq

wafarashid@lfu.edu.krd

\section{Hero Hassan Khzir}

Department of Accounting, College of Administration and Economics, Lebanese French University, Erbil, Kurdistan Region, Iraq

herohassan@Ifu.edu.krd

\section{ARTICLE INFO}

\section{Article History:}

Received: 24/7/2021

Accepted: 9/9/2021

Published: Autumn 2021

$\begin{array}{lr}\text { Keywords: } & \text { board } \\ \text { independence, } & \text { board } \\ \text { ownership, } & \text { board } \\ \text { meetings, financial } & \text { findormance, board } \\ \text { performateristics. } & \end{array}$

\begin{abstract}
This study investigated the effect of board characteristics on financial performance. The study examined board ownership, board independence and board meetings as the independent variables of the study and Return on Assets as the dependent variable which indicated the financial performance of the organization. The data was collected from companies from different industries spanning the years 2005 to 2016 From Iraqi Securities Commission and Stock Exchange in Iraq. The study was based on a deductive approach and a panel data but cross-sectional design. The data employed the panel data and multiple regression analysis. The data employed the panel data and multiple regression analysis with the aid of Microsoft Excel and Statistical Package for Social Sciences (SPSS). The results revealed a positive relationship between board
\end{abstract}


Doi:

10.25212/Ifu.qzj.6.4.39 independence and board ownership with financial performance. However, increase in board meetings was found to negatively affect the company's Return on Assets. The paper recommended that the management of listed companies maintain having more non-executive directors and independent directors with ownership as this enhanced objectivity and ensured alignment of interests between shareholders and the directors.

\subsection{Introduction}

This Section acts as the introduction to the study and highlights the elements for the whole study. It focuses on delivering the topic for the study and providing brief glimpses of what the study is all about as well as the framework upon which the study will be built on. The Paper presents such things like the problem statement, significance of the study, research hypotheses as well as the structure of the project. Issues of Board Characteristics cannot be emphasized enough. Recently, emphasis on Board Characteristics has increased prompted by the emergence of a lot of financial scandals. Some renowned companies collapsed as a result of bad Board Characteristics in ways that could have been avoided. in Kurdistan region there is a general lack of Board Characteristics according to Dovski (2015). As such, shareholders and stakeholders are interested in the activities of the board of directors in guarding and protecting their interests and investments.

The boards of directors are an integral part of any organization. They undertake duties on behalf of the shareholders and ensure that the business is delivering value as well as being a profitable, sustainable going concern. As such they are concerned with all matters that have to do with the governance of the organization and ensuring that the shareholders as well as other stakeholders' needs are met. One of the things they deal with is ensuring that there is high firm performance through monitoring and advising when needed. Shareholders are very much interested in having returns from their investments and are also concerned about their dividends. However, the board has many elements that may have an impact on firm performance especially those related to its composition like the size, independence, 


\section{QALAAI ZANISTSCIENTIFIC JOURNAL \\ A Scientific Quarterly Refereed Journal Issued by Lebanese French University - Erbil, Kurdistan, Iraq \\ Vol. (6), No (4), Autumn 2021 \\ ISSN 2518-6566 (Online) - ISSN 2518-6558 (Print)}

ownership, gender, age ratio of executive to non-executive directors and directors' education among others.

Organization performance is essential to the firm as it is the backbone of the organization and determines if the firm is going to be a going concern or not. It would also serve to assure the shareholders and stakeholders that the financial reporting in the organization can be trusted and they can have their wealth. However, there may be some characteristics in the board that may enhance or detract from this firm performance and it is the purpose of this paper to investigate the effect these characteristics have.

\subsection{Research Problem}

Despite significant advancements in corporate governance codes since 1978, as well as empirical conclusions from a wide body of research, good governance failed to avoid the recent global financial crisis (Siddiqui, 2015:218). As a result, the issue arises: does good governance assist businesses or is it simply a cost of doing business in today's global marketplace? Weak corporate governance processes were blamed for the 1997 economic crisis on the Southeast Asian stock market, which resulted in certain firm failures (Ali, D. J., \& Hamad, H. A in 2020). In a similar spirit, others blame the collapse of large firms in industrialized countries, such as Enron Corporation (Corp.) and WorldCom Incorporated, in part on globalization (Inc.). Aside from Global Crossing,

\subsection{Significance of the study}

The study is focused on the effect of board characteristics and firm performance. The available literature is inconclusive and studies that have been conducted continue to derive contradicting results with regards to whether the board positively or negatively affects the quality of audit. This information is crucial to the organizations in Kurdistan Region as it can help them know areas of strengths and weaknesses with regards to the board characteristics. In addition, Organizational performance is a vital element of listed companies and if there are any ways in which this can be negatively affected by the board, this information would be useful in devising methods of enhancing firm performance through the board. 


\section{QALAAI ZANISTSCIENTIFIC JOURNAL \\ A Scientific Quarterly Refereed Journal Issued by Lebanese French University - Erbil, Kurdistan, Iraq \\ Vol. (6), No (4), Autumn 2021 \\ ISSN 2518-6566 (Online) - ISSN 2518-6558 (Print)}

In addition, the study is also of great significance as it can add to the existing body of literature and perhaps come up with new contributions. There has been very little study in this area in the Northern Iraq and a study of this nature would provide light on the subject matter. It would also serve as a foundation for future studies that may be related to the topic.

\subsection{Research questions}

The major question for the study pertains to the effect of board characteristics on Organization performance. However, the board characteristics are further divided so as to shed light on the different facets of the board characteristics. These are divided into board ownership, independence and meetings.

1. Does board ownership has a positive significant on impact financial performance.

2. Board meetings has a positive significant impact on financial performance.

3. Does the increase in outside directors have any effect on the financial performance?

\subsection{Research hypotheses}

In line with the above questions, the researcher formulated the following hypotheses:

1. Null hypothesis: ownership of board by directors does not increase financial performance;

2. Null hypothesis: Increase in board meetings result in increase in financial performance

3. Null hypothesis: board independence does not have any impact on financial performance 


\section{Section Two}

\section{THEORTICAL FRAMEWORK AND LITERATURE REVIEW}

\subsection{Introduction}

This Section presents the detailed theoretical backgrounds of the study. It provides definitions and deeper understanding of board characteristics as well as financial performance. It goes into detail on each of the characteristics of the board that were chosen for this study as well as the ones chosen to represent Organization performance. In addition, it provides related theories and findings from other scholars in similar studies from across the globe.

\subsection{Board Independence}

Objectivity comes as a result of being free from bias. This trait is also required in the board of directors and this relates to the make-up of the board itself. The board consists of executive and non-executive directors. These would be internal or external, respectively. The internal directors have the responsibility to monitor the management's activities but the external directors would monitor both the internal directors and the management (Liu et al, 2015). The monitoring ensures that there is adherence to policies and incidences of insider dealing are curbed.

According to Syed et al (2016) if the external directors lack objectivity, then they would not be in a position to carry out their duties with due diligence. There were several theories put across to explain the components of board of directors' characteristics. These include the agency theory, stewardship theory, resource dependency theory and the stakeholder's theory. However, for this study the researcher will focus on the agency and the stewardship theory as they best represent the variables to be used.

\subsubsection{Stewardship theory}

The stewardship theory is the direct opposite of the agency theory. This theory focuses on the belief that agents in their capacity will conduct work for their organization expediently and rendering external people are unnecessary. This theory also posits that this would be successful if the insiders possessed enough power and authority. Afzalur (2018) pointed out that in small organizations, 


\section{QALAAI ZANISTSCIENTIFIC JOURNAL \\ A Scientific Quarterly Refereed Journal Issued by Lebanese French University - Erbil, Kurdistan, Iraq \\ Vol. (6), No (4), Autumn 2021 \\ ISSN 2518-6566 (Online) - ISSN 2518-6558 (Print)}

engaging the expertise of an independent director is rare as these tend to employ their own especially from families. However, this could present problems as that person's objective would have already been compromised.

\subsubsection{Agency theory}

According to Mohamed at all (2016), conflicts can arise between the management and the goals of the organization; however, this is solved by the presence of the board of directors and ultimately results in a decrease in agency costs as a result. The board of directors acts as agents for the shareholders, who are the owners of the business and ensure that they create and maximize wealth on these shareholders' behalf. In addition, as it is ideal to keep the ownership and the control of the business separate, the board act as the buffer or the mediator between the two, assuming control of the business for the owners and acting in the owners' best interests. The agency theory thus depicts the relationship between the board and the firm.

According to the agency theory, many internal directors would result in prevalence of conflicts within the organization. They explained that this is due to the subsequent increase in power which also means high chances of lack of objectivity and adversely affecting the monitoring process. External directors would be more objective and thus independent as they are distance themselves from the normal daily business (Brickley and Zimmerman, 2010). Findings by Bird et al (2020) corroborate the agency theory as they revealed that board independence affected financial performance. A positive and significant connection was revealed between the two. An increase in the board members had an adverse effect on the Chief Executive Office's power over that board and led to decreased return on assets and varied firm performance.

\subsection{Board meetings}

Board meetings are a vital part of the board of directors' activities. These are held at different intervals throughout the year on an annual, semiannual or quarterly basis. It is in these meetings that the directors hold discussions on the issues concerning the wellbeing of the organization like strategies on maximizing shareholder wealth, 


\section{QALAAI ZANISTSCIENTIFIC JOURNAL \\ A Scientific Quarterly Refereed Journal Issued by Lebanese French University - Erbil, Kurdistan, Iraq \\ Vol. (6), No (4), Autumn 2021 \\ ISSN 2518-6566 (Online) - ISSN 2518-6558 (Print)}

review firm performance and come up with policies as well as action plans. Some schools of thought have pointed out that the meetings also serve to strengthen the relations between the directors. There is a contradicting body of literature regarding the impact of meetings on financial performance. Some scholars pointed out that the methods that were employed to measure this relationship like the least squares' regression method disregarded the effect of culture and other firm characteristics hence the results would end up being different.

According to Ntim and Osei (2011), the frequency of board meetings implies the increased monitoring of management activities and a better control of activities. They explained that frequent meetings allowed directors to be abreast of the developments in the organization which in turn helped enhance their decision making as they will be doing it from an informed point of view. This was also supported by Al-Daoud et al (2016) who explained that frequent board meeting enhanced the process of problem solving and critical issues would be dealt with more urgency and in a timelier manner. However, contradicting results were found by Almontaser and Fadzil (2018) in their study in Jordan. Their findings revealed that the frequency of meetings did not predict financial performance in the Jordan banks.

Vefeas (1999) pointed out that frequent meetings are counterproductive and do not really bring that much benefit as they just focus on routine things. In addition, they are costly and direct the outside directors' attention away from their monitoring activities. These results corroborated those of Johl et al (2015) who contended that more meetings just result in energy being poured into things that are not a priority to the organization. They posited that board meetings should actually be less frequent but that the quality of the meeting is what matters the most.

\subsection{Board ownership}

Corporate governance issues include board ownership. Board members act as agents on behalf of the principals who are the shareholders. According to the principal-agent problem, there are usually problems created where there is an agent who is not the owner, as they can put their needs ahead of those of the principal. In most cases now, to prevent or reduce this problem, the board of directors also own 


\section{QALAAI ZANISTSCIENTIFIC JOURNAL \\ A Scientific Quarterly Refereed Journal Issued by Lebanese French University - Erbil, Kurdistan, Iraq \\ Vol. (6), No (4), Autumn 2021 \\ ISSN 2518-6566 (Online) - ISSN 2518-6558 (Print)}

shares so that they are invested in the company and its being wellbeing. By virtue of improving the company performance to suit their interests, they will also be furthering the interests of the other shareholders (Akinyomi, 2013). To determine board ownership, it depends on the quantity of shares held by the board of directors compared to the ones not owned by them (Meyer and De Vet, 2013).

The board structure is very important and this may differ in terms of family ownership, institutional ownership, and foreign ownership and so forth (Vu et al, 2017). Studies have shown that usually in small and medium companies the family members are the board members (Kao et al, 2019). This therefore means that there is usually no board member outside of the family. Institutional ownership on the other hand can consist of people like executive and non-executive directors, the audit committee and some supervisors. Fatah and et al (2021), indicate that Iraqi financial institutions are still not highly subject to international standards for internal auditing. Other countries have a lot of foreign direct investment ( $\mathrm{Li}$ and $\mathrm{Fu}$, 2017). In order to ensure that the local people retain ownership, some governments set up policies that ensure an ownership ratio between the foreign and the local people and the foreign ownership remains lower than the domestic one. According to Kao (2019) some of the problems that arise in listed companies that have a greater part of the shareholding compared to cash flow rights is that the majority shareholders can end up exploiting their control to further their interests to the detriment of the minority shareholders.

\subsection{Financial performance}

Finance activities form the backbone of any organization. As such improved financial performance is one of the many goals of companies. Financial performance allows the firm to be more liquid, to survive through difficult times as well as to grow. In addition, it can also help to fight competition if the firm has a healthy financial position (Kakanda et al, 2016). Shareholders are interested in the financial performance of the firm as a robust financial performance translates into a healthy return for them. 


\section{QALAAI ZANISTSCIENTIFIC JOURNAL \\ A Scientific Quarterly Refereed Journal Issued by Lebanese French University - Erbil, Kurdistan, Iraq \\ Vol. (6), No (4), Autumn 2021 \\ ISSN 2518-6566 (Online) - ISSN 2518-6558 (Print)}

According to Eluyela et al (2018), good corporate governance is associated with good financial performance. However, they also pointed out that this was also a matter of debate as some studies indicated that corporate governance had a negative effect whilst some found none.

Financial performance is quantitatively measured in different ways through financial ratios. The Return on Assets (ROA), Return on Capital Employed (ROCE) and the Return on Equity (ROE) are the ratios used to determine financial performance. These three methods are accounting based. Another method that is used is the Tobin's $Q$ and this is a market-based method that uses book values and market values.

\subsection{Empirical literature}

Al-Matar et al (2014) assessed the impact of board and audit committees on financial performance in Oman. The study was based on non-financial companies and the method used was a Tobin's $Q$ on the financial measurement. A regression analysis was conducted to test the hypotheses. The findings revealed a positive and significant relationship between the board characteristics of meeting and size and the Tobin's Q. However, board independence was found to be negatively related. Meyer and de Wet (2013) also examined effect of the board on financial performance using the Tobin's $Q$ and Earnings per Share as methods to measure financial performance. The study was conducted in South Africa and was based on the roles, duties and the composition of the board in relation to financial performance. Regression analysis, were also similarly adopted. The study revealed positive effects of board composition on earnings per share but no effects on the Tobin's Q. Board size was found to be positively related to both earnings per share and Tobin's Q. However, ownership was found to have significant adverse effects on both measures of financial performance.

Ntim and Osei (2011) conducted a study to establish the impact of board meetings on the performance of listed firms in South Africa over a 6year period. The study revealed that there was a positive relationship between the two and the more the meetings were held the better the performance. The study also showed that 


\section{QALAAI ZANISTSCIENTIFIC JOURNAL \\ A Scientific Quarterly Refereed Journal Issued by Lebanese French University - Erbil, Kurdistan, Iraq \\ Vol. (6), No (4), Autumn 2021 \\ ISSN 2518-6566 (Online) - ISSN 2518-6558 (Print)}

meetings resulted in improved financial performance. A similar study was conducted by Damilola et al (2018) in Nigeria on deposit money banks. Their study employed a panel regression method and the study revealed a positive association between frequency of board meetings and firm performance. They also recommended that the frequency of the meetings be increased in order to ensure that adherence to governance codes were maintained. In contrast, a study by Akpan (2015) in Nigeria on quoted companies showed a significant and negative relationship between the increased meetings and financial performance. The study utilized the same methods of panel regression to determine the relationship. On the other hand, a study by Aryani et al (2017) showed no effect of board meetings on financial performance.

Akinyomi (2013) assessed the effect of issues of corporate governance on financial performance in Nigeria. Among these he examined the director's shareholding, the board size, board composition and the Chief Executive Officer Duality effect. The Return on Equity and the Return on Capital Employed were used to measure the financial performance. The study employed Ordinary Least Squares regression to test for relationships between the variables. The findings revealed that board size and non-executive directors were strongly related to financial performance. However, the directors' stockholding was adversely related to financial performance in terms of Return on Equity but positively related to Return on Capital Employed.

In contrast, a study by Vu et al (2017) on Vietnam listed companies on impact of board structure on financial performance produced diverging results. The study found board size and board ownership to be significantly and positively related with Return on Assets but to have no significant effect on Return on Equity. Similar findings were also observed by Lin and Fu (2017) on Chinese firms. The study pointed out that increase in ownership resulted in an increase in financial performance. In addition, a study by Kao at al (2019) assessed effect of the ownership structure on financial performance in Taiwan.

The study examined the effects of director ownership, family ownership, foreign ownership as well as institutional ownership. A panel regression and two least squares regression was employed. The study revealed that all the types of ownership were significantly and positively related to financial performance. 


\section{QALAAI ZANISTSCIENTIFIC JOURNAL \\ A Scientific Quarterly Refereed Journal Issued by Lebanese French University - Erbil, Kurdistan, Iraq \\ Vol. (6), No (4), Autumn 2021 \\ ISSN 2518-6566 (Online) - ISSN 2518-6558 (Print)}

Assenga et al (2016) in contrast found no association between the external directors and financial performance in Tanzania. Unlike other studies that relied on quantitative data only, this study focused on panel data regression analysis as well as semi structured interviews.

Alfazular (2018) examined the effect of board independence on firm performance in Bangladesh. Both accounting and market related methods were employed on 135 listed firms to determine financial performance. The study revealed no connection between board independence and firm performance but found one between board size and firm performance. On the other hand, Al-Saidi (2020) examined the same variables in the banking sector in Kuwait's listed firms. The study employed a combination of ordinary least squares and two stages least squares regression analyses to establish the relationship. The study revealed a negative relationship between the board independence and the financial performance. In contrast, a study by Liu et al (2015) found a positive relationship between board independence and financial performance in China. The study also revealed that this relationship was truer for government institutions as well as those with low acquisition costs. Similar results were obtained by Palanniapan (2017) who found a positive and significant relationship between board independence and financial performance in Indian manufacturing industries. The study employed a multiple regression model.

\section{Section Three RESEARCH METHODOLOGY}

\subsection{Introduction}

The Section presents the methodology of the study, methods used as well as the definition of the variables where necessary. It also outlines the data set that was used as well as the years selected for the study and the methods employed.

\subsection{Variables}

The study aims to find the effects of board characteristic on financial performance. The independent variables of the study are board independence, board ownership and board meetings. Board independence was calculated as the proportion of board 


\section{QALAAI ZANISTSCIENTIFIC JOURNAL \\ A Scientific Quarterly Refereed Journal Issued by Lebanese French University - Erbil, Kurdistan, Iraq \\ Vol. (6), No (4), Autumn 2021 \\ ISSN 2518-6566 (Online) - ISSN 2518-6558 (Print)}

directors from outside the company; board ownership was provided in the financial statements as ownership rate and board meetings was calculated as the number of meetings conducted by the board of directors per year. The dependent variable of the study was financial performance reflected by the Return on Assets. The log of total assets was merely used as a control variable.

Return on Assets (ROA) is a measure of organization financial performance that establishes the extent to which the firm's assets are being used to generate profit. It thus reflects the efficiency of the management in that regard. The ROA is calculated as Net Profit divided by the average of total assets, or the ratio of profit before interest and taxes divided by the book value of average total assets.

Board independence refers to the state where the majority of board directors are from outside and are not employees of that company and their only tie to that company is as the directors. It shows the proportion of independent directors (external and non-executive directors) compared to the total number of directors. In terms of ownership, it simply refers to the level of stockholding owned that is the proportion of shares held by the board of directors in this case, calculated as a percentage. The ownership rates were already supplied in the financial statements.

\subsection{Research design}

A research design shows the steps taken to collect the panel data. The researcher used a descriptive study These designs offer a description of the situation and go on to further explain it. The researcher in this case is describing the state of the board characteristics then going on to explain it in relation to the financial performance and explaining the implications of those findings.

\subsection{Method}

The study was based on a quantitative approach. The researcher built the framework of this start using theories and empirical literature from other scholars. The hypotheses were then developed based on this literature and then tested. This approach is also ideal with data hence its selection as the method of choice. 


\section{QALAAI ZANISTSCIENTIFIC JOURNAL \\ A Scientific Quarterly Refereed Journal Issued by Lebanese French University - Erbil, Kurdistan, Iraq \\ Vol. (6), No (4), Autumn 2021 \\ ISSN 2518-6566 (Online) - ISSN 2518-6558 (Print)}

The study employed secondary data. The research explored board characteristics and financial performance using data from 2005 to 2016. The data was obtained from published financial statements of different companies from the year 2005 to 2016. The study only used public companies as they are the ones with easily available information. The advantage of secondary data is that it is convenient and in this case was specific to the exact requirements of the researcher. As well as there are some limitations of the secondary data:

1. Lack of validity.

2. Inappropriateness of the data

The researchers conducted a panel regression analysis with the use of Microsoft excel and then multiple linear regression analysis conducted using the Statistical Package for Social Sciences (SPSS). The following represents the regression model for the study that designed depended on previous studies:

Return on assets $i, t=\beta 0 i, t+\beta 1$ Board Ownership $i, t+\beta 2$ Board independence $i, t$ + B3 Board Meetings $i, t+\mu \mathrm{i}, \mathrm{t}$

the above represents Organization performance for company (i) at time (t)

\section{Section Four \\ DATA ANALYSIS}

The Section focuses on the analysis of the collected data. The researcher conducted descriptive statistics to determine the frequency of the variables for the study. Multicollinearity and Heteroskedasticity tests were conducted to determine the fitness of the model and check for similarities in items used. The researcher also conducted correlation and regression analysis to determine the strength and extent of the relationship between the variables.

\subsection{Descriptive statistics}

The table below shows the descriptive statistics for the independent and dependent variables. 


\section{QALAAI ZANISTSCIENTIFIC JOURNAL}

A Scientific Quarterly Refereed Journal Issued by Lebanese French University - Erbil, Kurdistan, Iraq

Vol. (6), No (4), Autumn 2021

ISSN 2518-6566 (Online) - ISSN 2518-6558 (Print)

Table 4.1 descriptive Statistics

\begin{tabular}{|c|c|c|c|c|c|}
\hline & ROA & OWN & BIND & BM & LOGAS \\
\hline$N$ & 29 & 29 & 29 & 29 & 29 \\
\hline Minimum & -1.636 & 20.77 & 44.5 & 2 & 8.72 \\
\hline Maximum & 1.06 & 94.31 & 82 & 8 & 9.91 \\
\hline Mean & $\begin{array}{r}- \\
0.0583\end{array}$ & 62.66 & 61.9689 & 4.3448 & 9.3791 \\
\hline Std. Deviation & 0.5771 & 23.89 & 14.467 & 2.109 & 0.3496 \\
\hline Skewness & $\begin{array}{r}- \\
0.8136 \\
\end{array}$ & -0.231 & 0.1798 & 0.4169 & $\begin{array}{r}- \\
0.3011\end{array}$ \\
\hline $\begin{array}{l}\text { Std. Error of } \\
\text { Skewness }\end{array}$ & 0.4335 & 0.433 & 0.4335 & 0.4335 & 0.4304 \\
\hline Kurtosis & 0.9935 & -1.501 & -1.856 & $\begin{array}{r}- \\
1.1894 \\
\end{array}$ & $\begin{array}{r}- \\
0.9295 \\
\end{array}$ \\
\hline $\begin{array}{l}\text { Std Error of } \\
\text { Kurtosis }\end{array}$ & 0.8452 & 0.845 & 0.8452 & 0.8452 & 0.8452 \\
\hline Mediun & 0.46 & 61.81 & 55 & 4 & 9.91 \\
\hline
\end{tabular}

The table above shows that on the highest board ownership was 94.31 whilst the minimum was 20.77. The Mean board ownership is $62.66 \%$. In addition, board independence shows a maximum of $82 \%$ and a minimum of $44.5 \%$. The average is $61.96 \%$ and this shows that the majority of the board members are non-executive directors and the board has a high independence. On the other hand, the highest number of board meetings recorded is 8 whilst the least is 2 . On average the number of meetings conducted was 4.34 , hence the board hold 4 meetings per year on average. Lastly, the largest return on assets was 1.06 whilst the least was -1.636 . The average ROA was -0.058 .

Table 4.2 Heteroskedasticity test

\begin{tabular}{ccc|c}
\multicolumn{2}{c}{} & & \multicolumn{2}{c}{ Collinearity } & Statistics \\
\multicolumn{2}{c}{ Model } & Tolerance & VIF \\
\hline \multirow{3}{*}{1} & BM & .781 & 1.281 \\
\cline { 2 - 4 } & OWN & .730 & 1.371 \\
\cline { 2 - 4 } & BIND & .839 & 1.192 \\
\cline { 2 - 4 } & LOGAS & .890 & 1.123 \\
\hline
\end{tabular}

a. Dependent Variable: ROA 


\section{QALAAI ZANISTSCIENTIFIC JOURNAL \\ A Scientific Quarterly Refereed Journal Issued by Lebanese French University - Erbil, Kurdistan, Iraq \\ Vol. (6), No (4), Autumn 2021 \\ ISSN 2518-6566 (Online) - ISSN 2518-6558 (Print)}

Next, the data was also tested for Heteroskedasticity test. The researcher employed the Test Glesjer in checking Heteroskedasticity of the data to ensure that the model has no such problem. In the Heteroskedasticity test, the sig value should be above 0.05 to conclude that there is no Heteroskedasticity whilst the opposite would mean its presence. The table above shows all sig values of above $0.05 ; 0.116$ for board ownership, 0.104 for board independence, 0.781 for board meetings and 0.890 for total assets. No Heteroskedasticity was detected therefore.

Table 4.2 Correlations

\begin{tabular}{|c|c|c|c|c|c|c|}
\hline & & ROA & $\mathrm{BM}$ & OWN & BIND & LOGAS \\
\hline \multirow[t]{3}{*}{ ROA } & Pearson Correlation & 1 & $-.402^{*}$ & .148 & .252 & .079 \\
\hline & Sig. (2-tailed) & & .031 & .444 & .187 & .685 \\
\hline & $\mathrm{N}$ & 29 & 29 & 29 & 29 & 29 \\
\hline \multirow[t]{3}{*}{ BM } & Pearson Correlation & $-.402^{*}$ & 1 & $.377^{*}$ & -.151 & .237 \\
\hline & Sig. (2-tailed) & .031 & & .044 & .434 & .216 \\
\hline & $\mathrm{N}$ & 29 & 29 & 29 & 29 & 29 \\
\hline \multirow[t]{3}{*}{ OWN } & Pearson Correlation & .148 & $.377^{*}$ & 1 & $-.385^{*}$ & -.097 \\
\hline & Sig. (2-tailed) & .444 & .044 & & .039 & .617 \\
\hline & $\mathrm{N}$ & 29 & 29 & 29 & 29 & 29 \\
\hline \multirow[t]{3}{*}{ BIND } & Pearson Correlation & .252 & -.151 & $-.385^{*}$ & 1 & .141 \\
\hline & Sig. (2-tailed) & .187 & .434 & .039 & & .466 \\
\hline & $\mathrm{N}$ & 29 & 29 & 29 & 29 & 29 \\
\hline \multirow[t]{3}{*}{ LOGAS } & Pearson Correlation & .079 & .237 & -.097 & .141 & 1 \\
\hline & Sig. (2-tailed) & .685 & .216 & .617 & .466 & \\
\hline & $\mathrm{N}$ & 29 & 29 & 29 & 29 & 29 \\
\hline
\end{tabular}

*. Correlation is significant at the 0.05 level (2-tailed).

The table above shows the correlation analysis which measures the relationship between independent and dependent variables. The table shows that board ownership is positively related with financial performance as measured by the Return on Assets at $14.8 \%$ which is weak correlation. A positive relationship is also observed between board independence and financial performance as shown by the 25.2\% association. However, a negative correlation was observed between board meetings and Return on Assets. The table shows a significant and negative relationship between the two as shown by the -0.40 value. 


\section{QALAAI ZANISTSCIENTIFIC JOURNAL \\ A Scientific Quarterly Refereed Journal Issued by Lebanese French University - Erbil, Kurdistan, Iraq}

Vol. (6), No (4), Autumn 2021

ISSN 2518-6566 (Online) - ISSN 2518-6558 (Print)

Table 4.4 Model estimation

\begin{tabular}{cr|rrl} 
Model R & R Square & $\begin{array}{l}\text { Adjusted R } \\
\text { Square }\end{array}$ & $\begin{array}{l}\text { Std. Error of the } \\
\text { Estimate }\end{array}$ \\
\hline 1 & $.649^{\mathrm{a}}$ & .421 & .325 & .474214527630349 \\
\hline
\end{tabular}

a. Predictors: (Constant), LOGAS, OWN, BIND, BM

The table above shows the suitability of the model. The $\mathrm{R}$ in the table represents the correlation of the independent variables to the dependent variable. The table shows that there is a $64.9 \%$ correlation between the variables meaning that $64.9 \%$ of the changes in financial performance can be explained by board ownership, board independence, and board meetings.

Table 4.5 ANOVAa

\begin{tabular}{|c|c|c|c|c|c|c|}
\hline & Model & Sum of Squares & Df & Mean Square & $F$ & Sig. \\
\hline \multirow[t]{3}{*}{1} & Regression & 3.931 & 4 & .983 & 4.370 & $.009^{b}$ \\
\hline & Residual & 5.397 & 24 & .225 & & \\
\hline & Total & 9.328 & 28 & & & \\
\hline
\end{tabular}

a. Dependent Variable: ROA

b. Predictors: (Constant), LOGAS, OWN, BIND, BM

The table above represents the Analysis of Variance (ANOVA). This shows if the independent variables can significantly as well as statistically predict the financial performance as measures by ROA. The $p$ value of the variables is 0.009 which is less than the significance value of 0.05 . It can thus be concluded that board independence, ownership and board meetings can statistically and significantly predict financial performance.

Table 4.6 Coefficients

\begin{tabular}{|c|c|c|c|c|c|c|}
\hline \multirow[b]{2}{*}{ Model } & & \multicolumn{2}{|c|}{ Unstandardized Coefficients } & \multirow{2}{*}{$\begin{array}{l}\text { Standardized } \\
\text { Coefficients } \\
\text { Beta } \\
\end{array}$} & \multirow[b]{2}{*}{$\mathrm{t}$} & \multirow[b]{2}{*}{ Sig. } \\
\hline & & $\mathrm{B}$ & Std. Error & & & \\
\hline \multirow[t]{5}{*}{1} & (Constant) & -4.452 & 2.544 & & -1.750 & .093 \\
\hline & BM & -.165 & .048 & -.603 & -3.433 & .002 \\
\hline & OWN & .013 & .004 & .525 & 2.890 & .008 \\
\hline & BIND & .013 & .007 & .332 & 1.956 & .062 \\
\hline & LOGAS & .373 & .272 & .226 & 1.373 & .183 \\
\hline
\end{tabular}

a. Dependent Variable: ROA 


\section{QALAAI ZANISTSCIENTIFIC JOURNAL \\ A Scientific Quarterly Refereed Journal Issued by Lebanese French University - Erbil, Kurdistan, Iraq \\ Vol. (6), No (4), Autumn 2021 \\ ISSN 2518-6566 (Online) - ISSN 2518-6558 (Print)}

A good regression model does not have multicollinearity hence the data was also tested for multicollinearity. This step was conducted in order to determine that there was equal in not similarity between the independent variables as presence of such would lead to strong correlations. According to Gujarati (2003) and other scholars the Variance Inflation Factor (VIF) should fall in the range of between 1 and 10 for it to be established there is no multicollinearity. The above table shows that the VIF for ownership, board independence, board meetings and total assets were $1.371,1.192,1.281$ and 1.123 respectively. All the values are above 1 and less than 10 , hence it can be concluded that there is no multicollinearity between the independent variables.

The table above shows the individual change effects of the independent variables in relation to the dependent variable. The table shows that an increase in a unit of ownership is results in an increase in financial performance by 0.013 units. The $p$ value for the board ownership is also 0.008 which is less than 0.05 and thus it can be concluded that the hypothesis that increased board ownership by directors has a positive impact on financial performance. Secondly, the board independence also shows a positive effect on financial performance as an increase in board independence can be seen to cause an increase in financial performance by 0.013 units. The $p$ value for the board independence variable is 0.062 . However, this value is greater than 0.05 and thus the effect is not significant. The hypothesis that, increase in outside directors increase financial performance was accepted as the researcher did not allude to any significance. The table also shows the beta value for board meetings as a negative value at -.165 . This means that more board meetings actually have adverse impact on the financial performance and results in a decrease in the ROA. The $p$ value for board meetings is 0.002 which is less than the significant value of 0.05 , hence the change is significant. The hypothesis that increases in number of board meetings adversely affects financial performance is thus accepted and the null hypothesis rejected. 


\section{QALAAI ZANISTSCIENTIFIC JOURNAL \\ A Scientific Quarterly Refereed Journal Issued by Lebanese French University - Erbil, Kurdistan, Iraq \\ Vol. (6), No (4), Autumn 2021 \\ ISSN 2518-6566 (Online) - ISSN 2518-6558 (Print)}

\subsection{Discussion}

The results revealed some interesting results with regards to board characteristics and financial performance. The results showed that on average the Return on Assets was negative. This result may not be that surprising considering that the Kurdistan region was going through an economic crisis for most of the time during the years between 2014 that were under study. According to Fatah (2018), these crises have been an impacting directly on the banking sector. The study revealed that on average there was high board independence of $61.9 \%$. This reflects that the majority of the board members are actually external and non-executive directors. The study further revealed a positive and significant relationship between board independence and financial performance as reflected by the correlation and regression analysis. These findings confirm and support the Agency Theory which alludes that an increase in external directors increases independence. They also support the findings of Akinyomi (2013), Palaniappan (2017) and Liu et al (2015) that increased number of non-executive directors improved financial performance as reflected by Return on Assets.

The results on effect of board meetings were in line with some of the studies of other scholars like Johl et al (2015) and Vefas (1999). The findings reflected a significant and negative relationship between board meetings and financial performance. The results showed that an increase in board meetings would reduce financial performance. The researcher assumes that increase in frequency of board meetings would use up valuable directors' time best used for other essential priorities. These were in contrast to the findings of Ntim and Osei (2011) and Damilola et al (2018) as these scholars found that increased meetings led to increased financial performance.

In terms of ownership, the results indicated a positive relationship between the board ownership and financial performance. Increased ownership by directors improves alignment between the shareholders' interests and the board interests. These results corroborate the findings of Vu et al (2017), Kao et al (2019) and Lin 


\section{QALAAI ZANISTSCIENTIFIC JOURNAL \\ A Scientific Quarterly Refereed Journal Issued by Lebanese French University - Erbil, Kurdistan, Iraq \\ Vol. (6), No (4), Autumn 2021 \\ ISSN 2518-6566 (Online) - ISSN 2518-6558 (Print)}

and Fu (2017) who found a positive and significant relationship between ownership and financial performance.

Since the study overall reflects a significant and positive relationship between board characteristics and financial performance; it is ideal that the responsible stakeholders take issues of corporate governance seriously and ensure that there are policies in place to help companies improve their corporate governance.

\section{Section Five CONCLUSIONS}

\subsection{Strengths}

The strength of the study is that it is a subject which has not been much researched in the Kurdistan Region. This means it can really be of valuable use especially given the problem of corporate governance in the country. Such a study like this can pinpoint exactly how the board can contribute or detract from improving financial performance. The study was also focused on different industries across the nation which adds to the value of the study.

\subsection{Limitations}

The study employed only an accounting-based method for the determination of financial performance. The study used Return on Assets as a measure of financial performance. Other measure of financial performance includes market-based methods apart from other accounting-based methods like the Return on equity and earnings per share. The study was also focused only on secondary data as well as quantitative data. In addition, the study focused on only a few of the board characteristics. Other characteristics like the CEO duality, board size and board composition were left out.

\subsection{Recommendations for the future studies}

Taking into account the above limitations for the study, the researcher recommends that future study be done using a mixed method to ensure results that are more enlightening. In addition, future studies can be done on comparison of accounting 


\section{QALAAI ZANISTSCIENTIFIC JOURNAL \\ A Scientific Quarterly Refereed Journal Issued by Lebanese French University - Erbil, Kurdistan, Iraq \\ Vol. (6), No (4), Autumn 2021 \\ ISSN 2518-6566 (Online) - ISSN 2518-6558 (Print)}

based and market value-based methods to determine the effect of the board characteristics on financial performance. Alternatively, this can also be done using different methods of the same group like using the ROA and the ROE and comparing results for both.

\subsection{Conclusions}

This study focused on the effect of board characteristics on financial performance. Results have revealed positive impact on the board independence and ownership whilst a negative effect was obtained on board meetings. The study showed that some companies held as much as 8 meetings a year. The implication for this study is that more resources are being poured into these meetings but they have no value addition in terms of financial performance. The researcher thus suggests that firms keep the meetings to a few sittings per year and that they center the discussions on key issues that affect performance and avoid frequent meetings as these are unnecessary. Another conclusion that can be drawn from the study is that of the agency relationship. The findings show that increase in external directors' results in independence as well as increased performance and that increased director ownership improves financial performance. The researcher suggests the firms in Northern Iraq maintain this status quo to ensure that objectivity is maintained as well as provide an incentive for directors to work harder to boot the firm's performance as their ownership keeps the interests of the shareholders aligned to theirs and eliminates the agency problem.

\section{References:}

Afzalur Rashid, (2018). Board independence and firm performance: Evidence from Bangladesh, Future Business Journal, Volume 4, Issue 1, Pages 34-49,

Akinyomi John (2013). Impact of Board Structure on Corporate Financial Performance. International Journal of Research in Commerce, IT and Management. 3. 135-139.

Akpan, Eden, Okon (2015). Corporate board meetings and company performance: empirical evidence from Nigerian quoted companies 


\section{QALAAI ZANISTSCIENTIFIC JOURNAL \\ A Scientific Quarterly Refereed Journal Issued by Lebanese French University - Erbil, Kurdistan, Iraq \\ Vol. (6), No (4), Autumn 2021 \\ ISSN 2518-6566 (Online) - ISSN 2518-6558 (Print)}

Al-Daoud, Khaleel \& Saidin, Siti \& Abidin, Shamharir. (2016). Board meeting and firm performance: Evidence from the Amman stock exchange. Corporate Board: role, duties and composition. 12. 10.22495/cbv12i2art1.

Al-Matari, Ebrahim \& Al-Swidi, Abdullah \& Hanim, Faudziah. (2014). The Effect of Board of Directors Characteristics, Audit Committee Characteristics and Executive Committee Characteristics on Firm Performance in Oman: An Empirical Study. Asian Social Science. 10. 10.5539/ass.v10n11p149.

Almontaser Abdallah Mohammad Qadorah, Faudziah Hanim Bt Fadzil (2018). The Effect of Board Independence and Board Meeting on Firm Performance: Evidence from Jordan, Journal of Finance and Accounting. Vol. 6, No. 5, pp. 105-109

Al-Saidi, M. (2020), "Board independence and firm performance: evidence from Kuwait", International Journal of Law and Management, Vol. ahead-of-print No. ahead-of-print. https://doi.org/10.1108/IJLMA-06-2019-0145

Aryani, Anni Y, Doddy Setiawan, Isna Putri Rahmawati (2017). Board meeting and firm performance. Proceedings of International Conference on Economics ICE P438 - P444 ISBN 978-967-0521-99-2

Assenga, M.P., Aly, D.A., \& Hussainey, K. (2018). The impact of board characteristics on the financial performance of Tanzanian firms. Corporate Governance, 18, 1089-1106..

Bird, R., Huang, P., \& Lu, Y. (2018). Board independence and the variability of firm performance: Evidence from an exogenous regulatory shock. Australian Journal of Management, 43(1), 3-26.

Ali, D. J., \& Hamad, H. A. (2021). The role of the cash flow statement to provide accounting information for the financial decision-making process:(Case study International Islamic Bank of Kurdistan in the year 2018). QALAAI ZANIST SCIENTIFIC JOURNAL, 6(2), 870-887.

Damilola Felix Eluyela, Olamide Oluwabusola Akintimehin, Wisdom Okere, Emmanuel Ozordi, Godswill Osagie Osuma, Simon Osiregbemhe Ilogho, Olufemi Adebayo Oladipo, (2018). Board meeting frequency and firm performance: examining the nexus in Nigerian deposit money banks, Heliyon,Volume 4, Issue 10

Doski, Shivan. (2015). The necessity of issuing a corporate governance code for the Kurdistan Region. journal of finance and accountancy. 18. 


\section{QALAAI ZANISTSCIENTIFIC JOURNAL \\ A Scientific Quarterly Refereed Journal Issued by Lebanese French University - Erbil, Kurdistan, Iraq \\ Vol. (6), No (4), Autumn 2021 \\ ISSN 2518-6566 (Online) - ISSN 2518-6558 (Print)}

Fatah, N. A., Hamad, H. A., \& Qader, K. S. (2021). The Role of Internal Audit on Financial Performance Under IIA Standards: A Survey Study of Selected Iraqi Banks. QALAAI ZANIST SCIENTIFIC JOURNAL, 6(2), 1028-1048.

Fatah, N. A. J. I. (2018). Factors affecting customers' decision for taking out bank loans: A case of Sulaymaniyah city commercial banks (Doctoral dissertation, Master thesis of Near East University).

Johl, S. Kaur, B.J. Cooper (2015). Board characteristics and firm performance: evidence from Malaysian public listed firms. J. Econ. Bus. Manag., 3 (2), pp. 239-243

Kao, Mao-Feng \& Hodgkinson, Iynn \& Jaafar, Aziz. (2018). Ownership structure, board of directors and firm performance: evidence from Taiwan. Corporate Governance: The international journal of business in society. 19. 10.1108/CG-04-2018-0144.

Kakanda, M, M, B. Salim, S. Chandren (2016). Review of the relationship between board attributes and firm performance. Asian J. Finance Account., 8 (1), pp. 168-218

Khudhair, Dheyaa \& Al-Zubaidi, Firas \& Raji, Ali. (2019). The effect of board characteristics and audit committee characteristics on firm performance. Management Science Letters. 9. 271-282. 10.5267/j.msl.2018.11.012.

Liu, Yu \& Miletkov, Mihail K. \& Wei, Zuobao \& Yang, Tina, 2015. "Board independence and firm performance in China," Journal of Corporate Finance, Elsevier, vol. 30(C), pages 223-244.

Meyer, Erik, JHvH de Wet (2013). The impact of board structure on the financial performance of listed South African companies. South Africa business journal. Volume 9, Issue 3, 2013

Ntim, Collins G. and Osei, Kofi A (2011). The Impact of Corporate Board Meetings on Corporate Performance in South Africa. African Review of Economics and Finance, Vol. 2, No. 2, pp.83-103

Palaniappan, G. (2017), "Determinants of corporate financial performance relating to board characteristics of corporate governance in Indian manufacturing industry: An empirical study", European Journal of Management and Business Economics, Vol. 26 No. 1, pp. $67-85$ 


\section{QALAAI ZANISTSCIENTIFIC JOURNAL \\ A Scientific Quarterly Refereed Journal Issued by Lebanese French University - Erbil, Kurdistan, Iraq}

Vol. (6), No (4), Autumn 2021

ISSN 2518-6566 (Online) - ISSN 2518-6558 (Print)

Syed Mohd Fuzi, Sharifah Faatihah \& Abdul Halim, Syahrina \& Khudzari, Julizaerma. (2016). Board Independence and Firm Performance. Procedia Economics and Finance. 37. 460465. 10.1016/S2212-5671(16)30152-6.

Vefeas, N., (1999). Board Meeting Frequency and Firm Performance. Journal of Financial Economics 53: pp. 113-142.

Vu, Manh-Chiên \& Phan, Thanh \& Le, Nhu. (2017). Relationship between board ownership structure and firm financial performance in transitional economy: the Vietnamese transition. Research in International Business and Finance. 45. 10.1016/j.ribaf.2017.09.002.

\section{كاريكهريى تايبه تمهندييه كانى ئهنجومهنى كاركِيّرى لهسهر ئهداى دارايى :كهيسى} هdوليّر

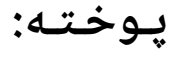

يرسى حهوكهمهى كوّميانياكان له دامهزراوهكاندا، گرنكييهكى زوّرى ههيه. بهشيّوهيهك كاريكهريى لهسهر لايهنه سهرهكييهكانى كار و يروّزه دادهنيّت. بهشيّك له تويّزينهوهكان ئهوه يِيشان دهدهن، كه

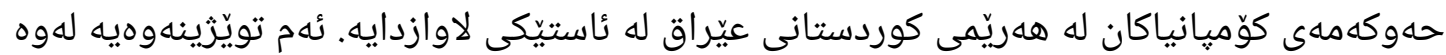

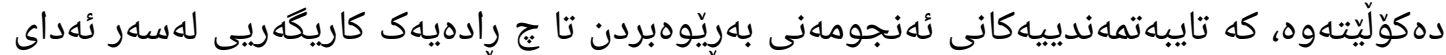

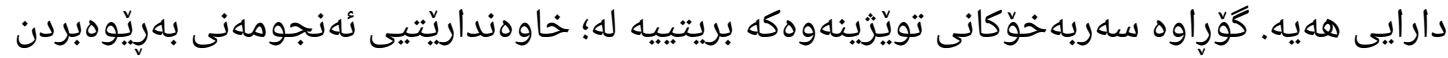

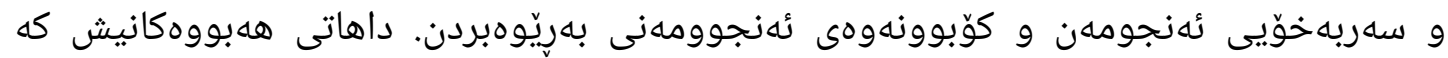

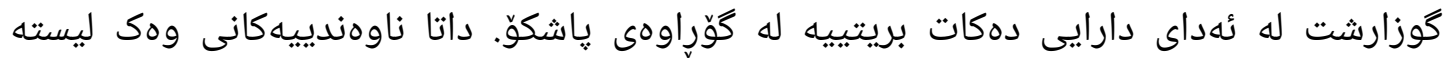

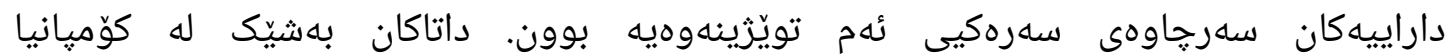

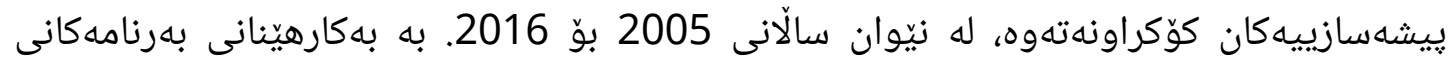
ئهكسلّ و (SPSS, 23) شيكارى بوّ داتاكان كران.

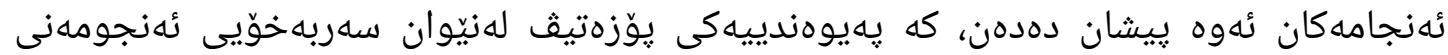

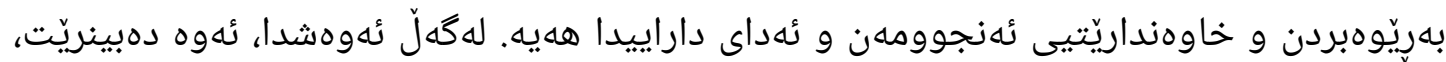

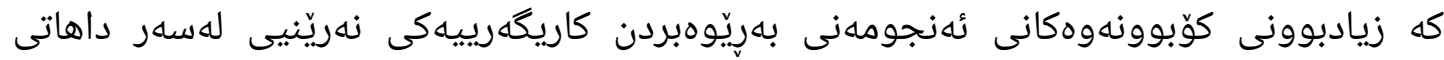




\section{QALAAI ZANISTSCIENTIFIC JOURNAL}

A Scientific Quarterly Refereed Journal Issued by Lebanese French University - Erbil, Kurdistan, Iraq

Vol. (6), No (4), Autumn 2021

ISSN 2518-6566 (Online) - ISSN 2518-6558 (Print)

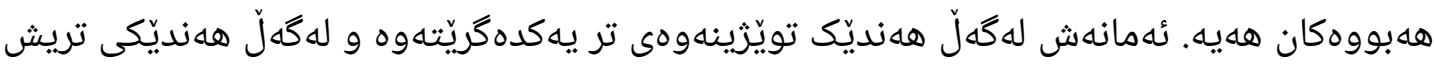

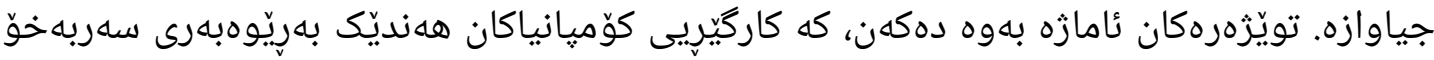

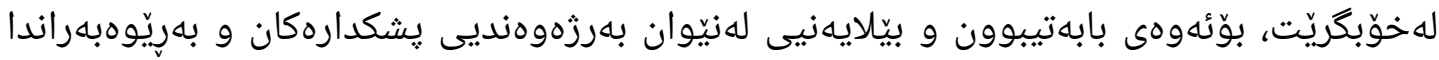

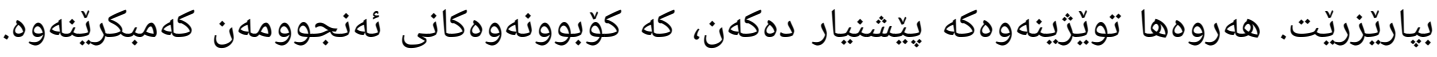

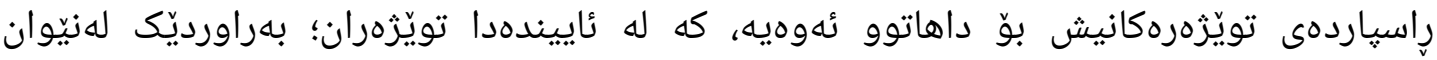
يِيّوهرهكانى ئهداى دارايى و زميّريارييدا بكهن.

\section{تأثير خصائص مجلس الإدارة على الأداء المالي: حالة أربيل}

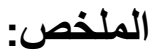

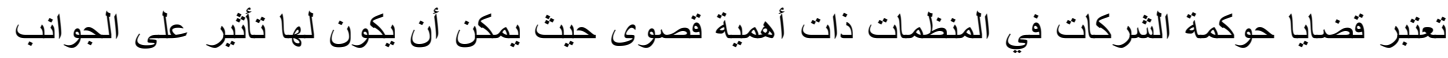

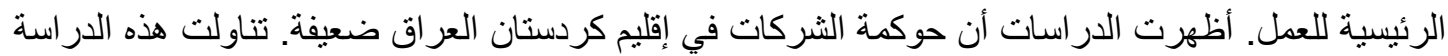

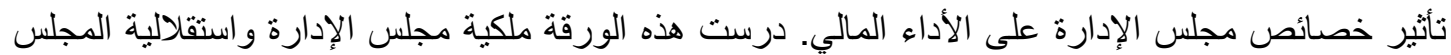

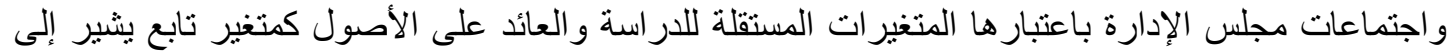

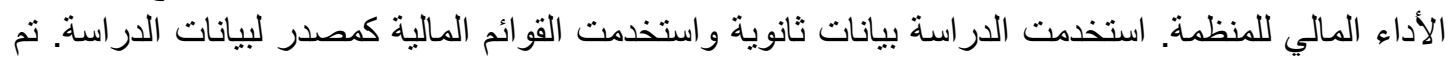

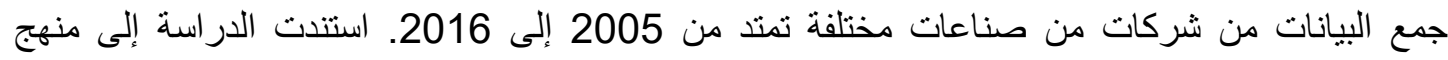

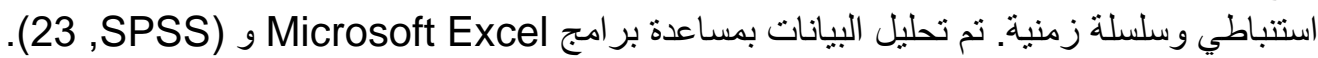

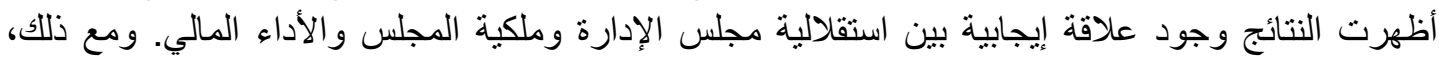

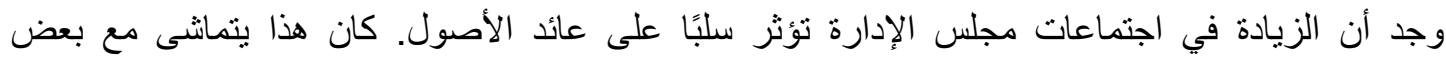

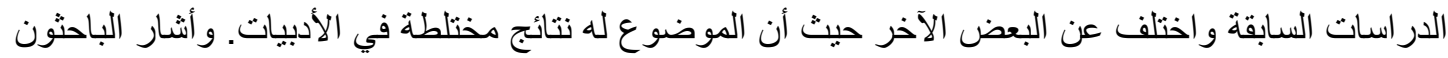

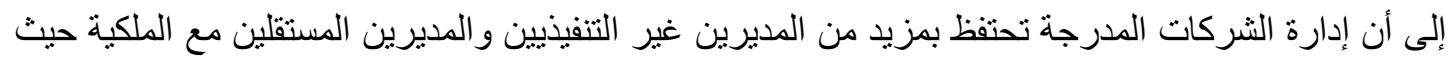

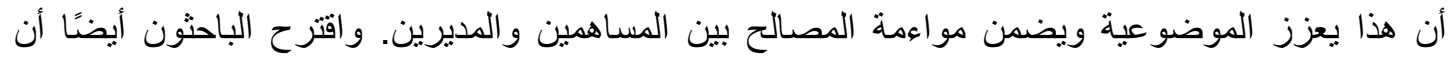

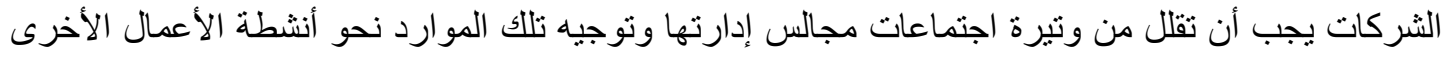

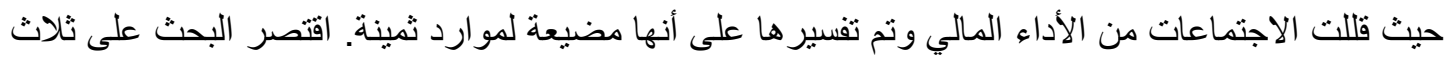

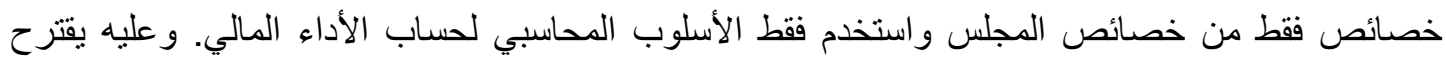

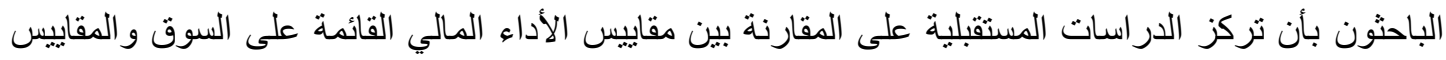

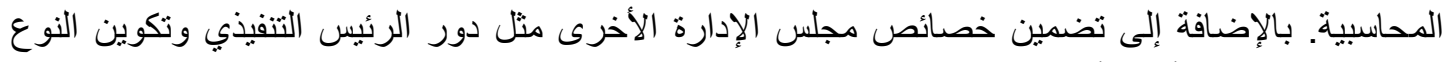

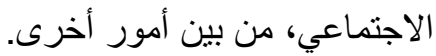

